\title{
Disclosure of Herbal Medicines Use on Mother and Children Health Care in Ternate Island Indonesia
}

\author{
Musiana $^{1}$, Hamidah Rahman ${ }^{1, *}$, Rosmila Tuharea ${ }^{1}$, Zubair Saing ${ }^{2}$ \\ ${ }^{1}$ Department of Public Health, Faculty of Health Sciences, Universitas Muhammadiyah Maluku Utara, Ternate, Indonesia \\ ${ }^{2}$ Faculty of Engineering, Universitas Muhammadiyah Maluku Utara, Ternate, Indonesia
}

Received September 24, 2021; Revised December 16, 2021; Accepted December 27, 2021

\begin{abstract}
Cite This Paper in the following Citation Styles
(a): [1] Musiana, Hamidah Rahman, Rosmila Tuharea, Zubair Saing, "Disclosure of Herbal Medicines Use on Mother and Children Health Care in Ternate Island Indonesia," Universal Journal of Public Health, Vol. 9, No. 6, pp. 492 498, 2021. DOI: 10.13189/ujph.2021.090618.
\end{abstract}

(b): Musiana, Hamidah Rahman, Rosmila Tuharea, Zubair Saing (2021). Disclosure of Herbal Medicines Use on Mother and Children Health Care in Ternate Island Indonesia. Universal Journal of Public Health, 9(6), 492 - 498. DOI: 10.13189/ujph.2021.090618.

Copyright $\bigcirc 2021$ by authors, all rights reserved. Authors agree that this article remains permanently open access under the terms of the Creative Commons Attribution License 4.0 International License

\begin{abstract}
Traditional medicine (TM) is still used by some tribes in Indonesia to treat and cure a variety of diseases, including maternal and child health care. A Biang, or Woman Traditional Healer (WTH), is a woman who uses herbal plants to practice TM for the health of mothers and children. Indeed, the herbs and ingredients used are frequently undocumented, putting the sustainability of TM in jeopardy. TM practices are also practiced on Ternate Island, and no research has been conducted to date on the identification and documentation of local knowledge of WTH in the use of herbal plants. The purpose of this study was to identify the characteristics of the WTH who practice on Ternate Island, as well as to identify local knowledge of WTH and to document herbal plants used in caring for the health of mothers and children. The descriptive explanatory research method was used, and data were collected using a semi-structured questionnaire guide. Snowball sampling was used to obtain respondents, and the data were analyzed using descriptive statistics. The average age of the thirty-eight WTH respondents was fifty-three years old. They have a primary school education $(92.1 \%)$, and some have attended traditional medicine training $(60.5 \%)$. All WTH use herbs in traditional medicine practice $(100 \%)$, and their healing skills were entirely inherited from their parents. WTH used 32 herbal plants, with postnatal care receiving the most attention. Given the significance of TM using herbal plants, more research is needed to determine the safety of these plants.
\end{abstract}

Keywords Maternal and Child Health, Herbal
Medicine, Traditional Medicine, Traditional Knowledge

\section{Introduction}

Traditional medicine (TM) systems are still valued, particularly in developing countries [1-3]. Indonesia recognizes the TM system as well, employing a wide range of medicinal plants to treat a variety of diseases [4]. Even in the age of modern computational pharmacology, TM plants play an important role in the treatment of a variety of ailments [5]. Similarly, many modern drugs are based on information about the use of herbs in traditional knowledge systems of TM that has been subjected to extensive clinical testing [6-8]. Artemisia апnиа is used as an antimalarial, Silibum marianum is used as a hepatoprotective, Taxus brevifolia is used in the treatment of lung, ovarian, and breast cancers, and many other herbs are currently used as raw materials in the production of modern medicine [7], [9].

The use of herbal plants (HP) in the TM system has several advantages, including a treatment method derived from indigenous and local culture [8], [10-11], the ease of obtaining herbs [12], and fewer side effects [5], [12-14]. TM using HP, on the other hand, is in short supply and may become extinct. According to some reports, there is a risk of HP resource extinction, as well as the possibility of finished over or data loss on traditional herbal recipes. Continuous harvesting without replanting or conservation 
can lead to the extinction of HP. Climate change also contributes to plant extinction in some areas, resulting in dead plants [15]. Another issue is that land and HP habitat are being over-exploited as a result of rapid development [5], [15]. Furthermore, the threat of losing information about prescription herbal ingredients as a result of the treatment methods was only passed on to the closest family members without proper notes or documentation [16]. Even if a few notes or documentation are discovered, they are only done in a specific language that, of course, only a certain group of people understand [17]. In order to avoid the loss of information on the use of herbs, it is critical to keep meticulous records and documentation in the practice of TM using herbs [5], [10].

Many studies have been published on the use of HP in the medical system in various parts of the world, including Thailand [6], [16], Ethiopia [10-11], Saudi Arabia [12], Italy [15], India [8], and many others. Among those who use HP to care for themselves and their families are women [7]. Women's health care with HP, including treatment of gynecological problems with Amaranthus sp [18] and care during pregnancy with Zingiber officinale [13], [19]. Similarly, mothers use HP for the care and treatment of their children if they become ill [4], [20-21]. The World Health Organization (WHO) also supports the practice of TM by recommending a 2014-2023 strategy for TM that each tribe can safely practice [6], [22]. The use of TM for maternal and child health care has been reported by several tribes from various countries, and such TM practices are also found in Indonesia. There have been studies on the use of HP for maternal and child health care in Indonesia [23-25], but the practice of TM for the Ternate Island tribe has not been reported. Similarly, data on the extent of local knowledge of WTH on Ternate Island about the benefits of HP are still limited.

The purpose of this study was to characterize the WTH on Ternate Island while also identifying their local knowledge in carrying out TM practices using HP. Furthermore, HP type identification was carried out to supplement the documentation of HP that grows on Ternate Island. This study contributed to efforts to preserve the practice of TM. Moreover, the results were used as the initial data to identify the source of the raw material for a new drug for maternal and child health care.

\section{Methods}

Ternate Island was the site of the study. Ternate Island is in eastern Indonesia, in the Maluku Islands group, specifically in the northern part of Maluku. Ternate is located between $0^{\circ} 25^{\prime} 41.82$ "and $1^{\circ} 21^{\prime} 21.78^{\prime \prime}$ North latitude and $126^{\circ} 7^{\prime} 32^{\prime \prime}$ and $127^{\circ} 26^{\prime} 23.12^{\prime \prime}$ East longitude. Ternate Island has a total area of $5,709.72 \mathrm{~km}^{2}$, divided into $162.17 \mathrm{~km}^{2}$ of land and $5,547.55 \mathrm{~km}^{2}$ of sea. The climate on Ternate Island is tropical [26], as present in Fig. 1.

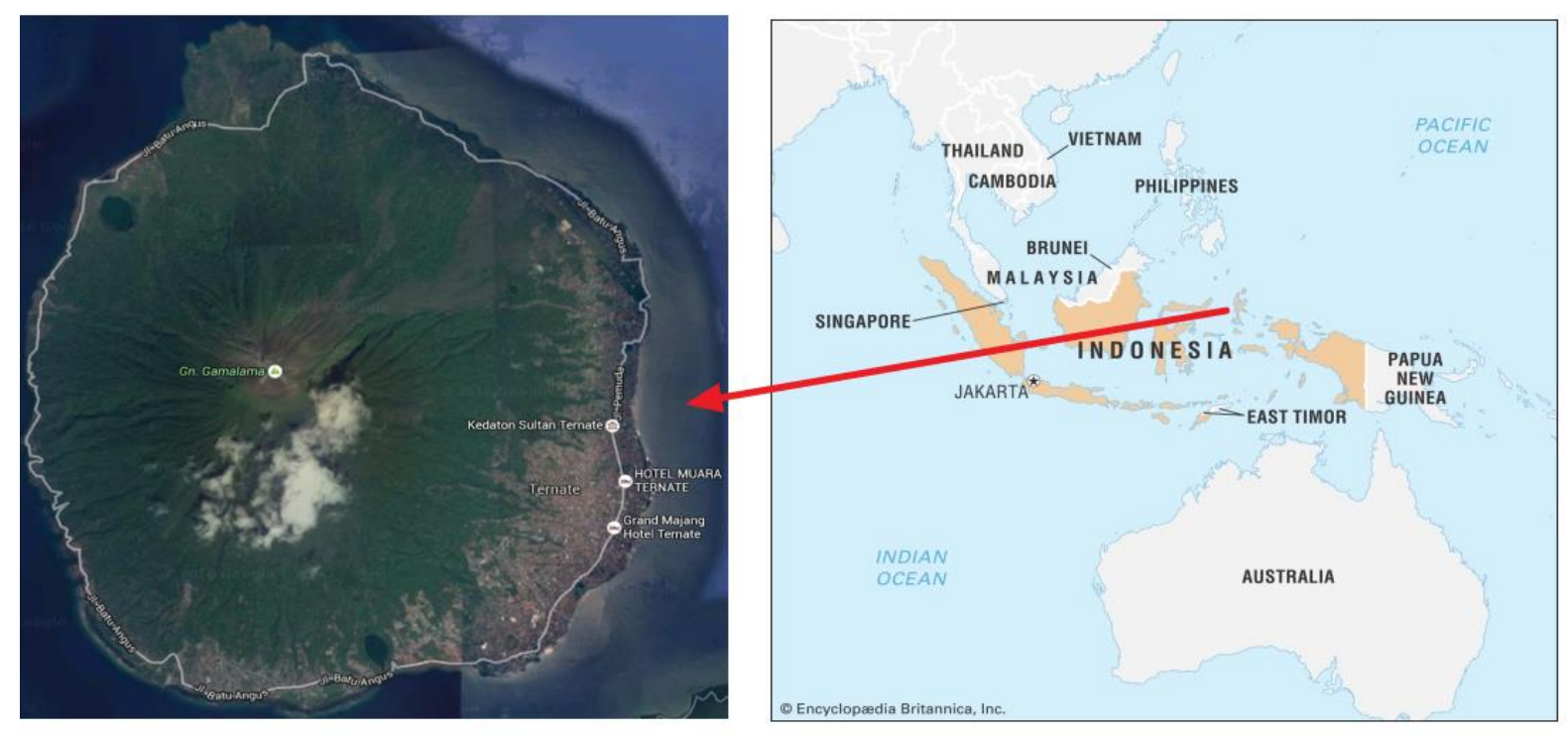

Figure 1. The map of study location 
Respondents were WTH who practice maternal and child health care in Ternate Island which were by snowball sampling. Snowball sampling was carried out in a way, namely in the early stages of the study, six of WTH were found. Of the six of them, a search was carried out for the candidate respondents who have the same characteristics, and so on, so that at the end of the study thirty-eight were obtained. This study was completed with informed consent for each respondent. Informed consent contains the provision of information regarding the involvement of every respondent as the subject of the study. In addition, there was also a statement of consent from each respondent to participate in this study voluntarily.

Data were collected through a face-to-face survey which was completed with a semi-structured questionnaire. The questionnaire's questions were used to collect all the data covering the characteristics of WTH. The data was processed by descriptive statistics such as frequency and percentage which is also called univariate analysis. The ethno-botanical data were collected by grouping all types of HP mentioned by WTH based on the type of service practice in maternal and child health care. The data and the results were presented in tables and narratives.

\section{Results}

Thirty-eight WTH from Ternate Island participated in the study. The WTH's average age was around fifty-three years old, and they were all married. The majority of WTH have completed primary school, and up to $60.5 \%$ have received TM training. Other characteristics of WTH include the fact that they learned how to practice TM from their parents, and that all use HP in the care of mothers and children. WTH treated more than ten patients per month on average. Table 1 displays the characteristics of WTH.

Table 2-5 contains the HP used by WTH for maternal and children health care, respectively.

Table 1. Socio-demographic characteristics of the WTH in Ternate Island $(n=38)$

\begin{tabular}{|c|c|c|c|}
\hline Characteristic & Frequency & Percentage (\%) & $\begin{array}{c}\text { Mean } \pm \text { SD } \\
\text { (year) }\end{array}$ \\
\hline Age & - & - & $53.3 \pm 4.5$ \\
\hline \multicolumn{4}{|l|}{ Marital status } \\
\hline Unmarried & 0 & 0 & \\
\hline Married & 38 & 100 & \\
\hline \multicolumn{4}{|l|}{ Level of education } \\
\hline None & 0 & 0 & \\
\hline Primary school & 35 & 92.1 & \\
\hline High school & 3 & 7.9 & \\
\hline \multicolumn{4}{|c|}{ Have attended health care training } \\
\hline Yes & 23 & 60.5 & \\
\hline No & $\begin{array}{l}23 \\
15 \\
\end{array}$ & 39.5 & \\
\hline \multicolumn{4}{|c|}{ Average patients/month } \\
\hline $1-3$ & 5 & 13.2 & \\
\hline $4-6$ & 12 & 31.6 & \\
\hline $7-9$ & 10 & 26.2 & \\
\hline$\geq 10$ & 11 & 29.0 & \\
\hline \multicolumn{4}{|l|}{ Healing skills of } \\
\hline Parents & 38 & 100 & \\
\hline Another family & 0 & 0 & \\
\hline Friend & 0 & 0 & \\
\hline Other & 0 & 0 & \\
\hline \multicolumn{4}{|c|}{$\begin{array}{l}\text { Using herbs in mother-child health } \\
\text { care practice }\end{array}$} \\
\hline Yes & 38 & 100 & \\
\hline No & 0 & 0 & \\
\hline
\end{tabular}

Table 2. Herbal plants used by WTH on postnatal care in Ternate Island

\begin{tabular}{|c|c|}
\hline Indications & Herbal plants \\
\hline Milk production and secretion & $\begin{array}{l}\text { Drumstick tree (Moringa oleifera); Katuk (Sauropus androgynus); banana flower } \\
\text { (Musa paradisiaca) }\end{array}$ \\
\hline Shrink and warm the stomach after giving birth & $\begin{array}{l}\text { Turmeric (Curcuma domestica } \mathrm{L} .) ; \text { Kencur (Kaempferia galanga } \mathrm{L} .) \text {; Ginger } \\
\text { (Zingiber officinale); Cinnamon (Cinnamomum verum); Areca nut (Areca catechu) }\end{array}$ \\
\hline Increase stamina & $\begin{array}{c}\text { Miyana leaf (Coleus scutellarioides); Nutmeg leaf (Myristica fragrans); Clove leaf } \\
\text { (Syzygium aromaticum) }\end{array}$ \\
\hline Improve blood circulation & $\begin{array}{l}\text { Nutmeg leaf (Myristica fragrans); Clove leaf (Syzygium aromaticum); banana flower } \\
\text { (Musa paradisiaca) }\end{array}$ \\
\hline
\end{tabular}


Table 3. Herbal plants used by WTH for caring during pregnancy in Ternate Island

\begin{tabular}{cc}
\hline Indications & Herbal plants \\
\hline Increase appetite & Areca nut (Areca catechu) \\
Blood booster & Lemongrass (Cymbopogon nardus L); Red Jatropha (Jatropha gossypiifolia) \\
Horning sickestension & Ginger (Zingiber officinale) \\
Hyperting & Garlic (Allium sativum); Celery leaf (Apium graveolens L.) \\
\hline
\end{tabular}

Table 4. Herbal plants used by WTH on childbirth assistance in Ternate Island

\begin{tabular}{cc}
\hline Indications & Herbal plants \\
\hline Childbirth facilitates & $\begin{array}{c}\text { Caricature plant (Graptophyllum pictum L.), Katang leaf (Ipomoea pes-caprae); Gedi leaf } \\
\text { (Abelmoschus manihot) Orthosiphon aristatus leaf; Castor leaf (Ricinus communis); } \\
\text { Jackfruit root (Artocarpus heterophyllus) }\end{array}$ \\
Lemongrass (Cymbopogon nardus L.); Ginger (Zingiber officinale); Turmeric (Curcuma \\
Removing the remnants of dirty blood \\
$\begin{array}{c}\text { demostica } \text { L.); Tamarind (Tamarindus indica); Galangal (Alpinia galanga); Java ginger } \\
\text { (Curcuma zanthorrhiza) }\end{array}$
\end{tabular}

Table 5. Herbal plants used by WTH on baby and child health care in Ternate Island

\begin{tabular}{|c|c|}
\hline Indications & Herbal plants \\
\hline Fever reducer & Jathropa leaf (Jathropa curcas L.); Lime fruit (Citrus aurantiifolia); Alloe vera L. \\
\hline Treat child seizures & Soursop leaf (Annona muricata L.) \\
\hline Baby skin cleanser & Ylang flower (Cananga odorata); Bitter melon (Momordica charantia L.) \\
\hline Mucus cough & Jathropa leaf (Jathropa curcas L.) \\
\hline Diarrhea & Guava leaf (Psidium guajava L.); Soursop leaf (Annona muricata L.) \\
\hline Fungus in mouth & Patchouli (Pogostemon cablin) \\
\hline
\end{tabular}

\section{Discussion}

The WTH, like tribes in other countries, particularly in developing countries, continues to rely on traditional medicines as a means of maintaining and treating health. This also applies to maternal and child health care and treatment. Malaysia [14], [27], Indonesia [20, 23, 28], Bangladesh [29], Nepal [30], Pakistan [18], Ethiopia [13, 32], Italy [31], Africa [2, 33, 34], and Palestine [35] have all used TM for maternal and child health care. Women are the primary consumers of herbal medicines, according to the number of reports from these studies.

This is the first study to reveal WTH in Ternate Island's knowledge of the use of HP in treating and improving maternal and child health. The practice of TM, which is run by the WTH on Ternate Island, is still active and is regarded as significant in the alternative medicine community. According to the findings of these studies, the average number of patients treated by the WTH in a month was four (data in Table 1). Biang or WTH use HP and medicinal herbs that they have prepared themselves in their medical practice. Biang is the term used by Ternate residents to describe a woman who uses TM to treat and cure maternal and child diseases. The data from this study shows that the knowledge and skills of all WTH (100\%) in running TM were obtained directly from their parents, which is consistent with the statement that TM practice is typically passed down through the immediate family [5]. The majority of WTH (60.5\%) have received TM training to improve their skills.

Local knowledge of the WTH about the different types of HP, their benefits, and their skills in preparing herbal medicines for maternal and child health care are well documented in this study. WTH's maternal and child health services include postnatal maternal care, care for women during pregnancy, maternal assistance during childbirth, and health care for infants and children. The mother's postpartum care includes assistance in facilitating the production of breast milk, tightening the abdomen after giving birth, and increasing stamina and blood circulation after birth (as shown in Table 2). Moringa leaves have the ability to improve both the quality and quantity of breast milk. Moringa contains phytosterols, which act as a galactagogue, stimulating breast milk secretion [36-38]. Similarly, katuk leaves can boost breast milk production $[28,39]$. Breast milk secretion has also been reported to be stimulated by banana flowers [40]. Postnatal care is also important for restoring the mother's stamina after giving birth. Nutmeg, clove, turmeric, galangal, ginger, and cinnamon are also used in TM to boost women's stamina after giving birth [41-43], as WTH did on Ternate Island.

The WTH on Ternate Island provided TM practices during pregnancy to increase pregnant women's appetites, prevent blood deficiency or anemia, reduce nausea and vomiting during pregnancy, and treat hypertension during pregnancy (as shown in Table 3). Symptoms of nausea, vomiting, heartburn, and constipation are common in pregnant women. Typically, these symptoms are self-treated with traditional medicine [19]. Ginger (Zingiber officinale) was widely reported to be used by pregnant women with an indication for nausea and vomiting $[13,19,44]$. Similarly, ginger is used by WTH in Ternate Island to reduce nausea and vomiting during pregnancy. WTH in Ternate Island used garlic and celery-containing ingredients to treat hypertension during pregnancy. Hajj and Handayani $[19,45]$ also reported the 
use of garlic (Allium sativum) and celery (Apium graveolens L.) as antihypertensive herbs. There was a WTH using areca nut to stimulate the mother's appetite during pregnancy. Local communities in Asia chew areca nut to stimulate saliva secretion [46]. Nonetheless, the use of areca nut for pregnant and lactating women needs to be researched further, given that several studies have found areca nut consumption to be harmful to pregnant women $[47,48]$.

WTH's delivery assistance activities include facilitating birth and cleaning up the remnants of dirty blood after birth (as shown in Table 4). Graptophyllum pictum L., Ipomoea pes-caprae, Abelmoschus manihot, Orthosiphon aristatus, Ricinus communis, and Artocarpus heterophyllus were some of the HP used by WTH on Ternate Island to help facilitate childbirth. Some of these HP have been shown to have oxytocic and labour-inducing properties [49, 50].

The WTH on Ternate Island not only cares for mothers, but also for the health of babies and children. WTH mentions health treatments for babies and children such as reducing fever, treating seizures, cleaning new-born skin, slimy treating coughs, diarrhea, and treating fungi that are commonly found in the baby's mouth (as shown in Table 5). Guava leaves have been reported to be antidiarrheal [51], while jathropa leaves are used to treat fever, colds, and cough [52].

The prevalence of HP use in women varies depending on factors such as geographic location, ethnicity, cultural traditions, and socioeconomic status, among others. Aside from the use of HP in traditional treatment methods, experience, skills passed down from generation to generation, education, and training [14, 19, 35] are all important considerations. To support the use of HP, it is necessary to locate the appropriate scientific evidence for the use, which may aid in the formation of a correct understanding of HP. As a result, it is necessary to develop TM from a pharmacology standpoint, so that mothers and children can be treated based on local wisdom as well as user safety, particularly for pregnant women, fetuses, infants, and children [23, 53, 54]. To reduce the risk of endangering the lives of fetuses and infants, pregnant and lactating women, as well as WTH, should be educated on the proper use of HP during pregnancy and lactation [19]. In this regard, some studies suggest studying the safety of herbal use in pregnant and lactating mothers [2, 13, 14, 19, 33]. As one example, areca nut has been linked to adverse effects on pregnant women and foetuses [48]. As a result, extensive research on the safety of plants used in traditional medicine practice is required. Another critical point is to increase WTH's understanding of the safety of administering HP to their patients, specifically women, pregnant women, breastfeeding mothers, infants, and children.

\section{Conclusions}

Ternate Island has maintained a tradition of traditional medicine based on herbal plants to this day. All the thirty-eight women traditional healers who responded used herbal plants, and their healing abilities were entirely inherited from their parents. There were 32 herbal plants used by women traditional healers for postnatal care, pregnancy care, childbirth assistance, and child health care. The majority of the herbal plants used have already been reported in accordance with the purpose of treatment, but some of the plants have not been reported in accordance with the purpose of therapy. To ensure the safe use of herbal plants for maternal and child health, scientific evidence-based research must be conducted to reveal the therapeutic purposes and adverse toxicity to mother and child health.

\section{Acknowledgement}

Thank you to the Universitas Muhammadiyah Maluku Utara for funding this research through the LP3M internal research grant program.

\section{REFERENCES}

[1] Ambu G, Chaudhary RP, Mariotti M, et al., "Traditional uses of medicinal plants by ethnic people in the Kavrepalanchok district, Central Nepal," Plants, Vol. 9, No. 6, 2020. www.mdpi.com/2223-7747/9/6/759 (accessed 2 Jun 2021).

[2] Nergard CS, Ho TPT, Diallo D, et al., "Attitudes and use of medicinal plants during pregnancy among women at health care centers in three regions of Mali, West-Africa," J Ethnobiol Ethnomed, Vol. 11, No. 73, 2015. www.ncbi.nlm.nih.gov/pmc/articles/PMC4600315/ (accessed 5 Jun 2021).

[3] Nyeko R, Tumwesigye NM, Halage AA., "Prevalence and factors associated with use of herbal medicines during pregnancy among women attending postnatal clinics in Gulu district, Northern Uganda," BMC Pregnancy Childbirth, Vol. 16, No. 296, 2016. www.bmcpregnancychildbirth.biomedcentral.com/articles/ 10.1186/s12884-016-1095-5 (accessed 2 Jun 2021).

[4] D'Arqom A, Nasution Z., "Herbal medicine perception and practice among childbearing mother with medical education background in Bandung: a preliminary study," Trad Med J, Vol. 19, No. 106, 2014.

[5] Karunamoorthi K, Jegajeevanram K, Vijayalakshmi J, et al., "Traditional medicinal plants: A source of phytotherapeutic modality in resource-constrained health care settings," J Evid Based Complementary Altern Med, Vol. 18, 2013, pp. 67-74. 
[6] Phumthum M, Balslev H, Kantasrila R, et al., "Ethnomedicinal plant knowledge of the Karen in Thailand," Plants Vol. 9, No. 7, 2020. www.mdpi.com/2223-7747/9/7 /813 (accessed 2 Jun 2021).

[7] Seidel V., "Plant-derived chemicals: A source of inspiration for new drugs," Plants, Vol. 9, No. 11, 2020. www.mdpi.com/2223-7747/9/11/1562 (accessed 7 Jun 2021).

[8] Ojha SN, Tiwari D, Anand A, et al., "Ethnomedicinal knowledge of a marginal hill community of Central Himalaya: diversity, usage pattern, and conservation concerns," J Ethnobiol Ethnomed, Vol. 16, No. 29, 2020. www.ethnobiomed.biomedcentral.com/articles/10.1186/s1 3002-020-00381-5 (accessed 2 Jun 2021).

[9] Djordjevic SM., "From medicinal plant raw material to herbal remedies," www.intechopen.com/books/aromatic-a nd-medicinal-plants-back-to-nature/from-medicinal-plant-r aw-material-to-herbal-remedies (accessed 5 Jun 2021).

[10] Teka A, Asfaw Z, Demissew S, et al., "Medicinal plant use practice in four ethnic communities (Gurage, Mareqo, Qebena, and Silti), South Central Ethiopia,"J Ethnobiol Ethnomed, Vol. 16, No. 27, 2020. www.ethnobiomed.bio medcentral.com/articles/10.1186/s13002-020-00377-1 (accessed 2 Jun 2021).

[11] Tuasha N, Petros B, Asfaw Z., "Medicinal plants used by traditional healers to treat malignancies and other human ailments in Dalle District, Sidama Zone," Ethiopia. J Ethnobiol Ethnomed, Vol. 14, No. 15, 2018. www.ncbi.nlm.nih.gov/pmc/articles/PMC5813379/ (accessed 1 Jun 2021).

[12] Aati H, El-Gamal A, Shaheen H, et al., "Traditional use of ethnomedicinal native plants in the Kingdom of Saudi Arabia," J Ethnobiol Ethnomed, Vol. 15, No. 2, 2019. www.ethnobiomed.biomedcentral.com/articles/10.1186/s1 3002-018-0263-2 (accessed 5 Jun 2021).

[13] Laelago T, Yohannes T, Lemango F., "Prevalence of herbal medicine use and associated factors among pregnant women attending antenatal care at public health facilities in Hossana Town, Southern Ethiopia: facility based cross sectional study," Arch Public Health, Vol. 74, No. 7, 2016. www.ncbi.nlm.nih.gov/pmc/articles/PMC4753650/ (accessed 2 Jun 2021).

[14] Mohamad TAST, Islahudin F, Jasamai M, et al., "Preference, perception and predictors of herbal medicine use among Malay women in Malaysia, Patient Prefer Adherence, Vol. 20, 1829, 2019, pp. 37.

[15] Petelka J, Plagg B, Saumel I, et al., "Traditional medicinal plants in South Tyrol (northern Italy, southern Alps): biodiversity and use," J Ethnobiol Ethnomed, Vol. 16, No. 1, 2020. www.ncbi.nlm.nih.gov/pmc/articles/PMC7690129/ (accessed 5 Jun 2021).

[16] Junsongduang A, Kasemwan W, Lumjoomjung S, et al., "Ethnomedicinal Knowledge of Traditional Healers in Roi Et, Thailand," Plants, Vol. 9, No. 9, 2020. www.ncbi.nlm.nih.gov/pmc/articles/PMC7570034/pdf/pla nts-09-01177.pdf (accessed 5 Jun 2021).

[17] Mulyani H, Widyastuti SH, Ekowati VI., "Herbal plants as traditional medicinal herbs against diseases in the fiber of primbon jampi jawi volume I," Journal of Humanities Research, Vol. 21, 2016, pp. 73-91. (In Indonesian)
[18] Aziz MA, Khan AH, Ullah H, et al., "Traditional phytomedicines for gynecological problems used by tribal communities of Mohmand Agency near the Pak-Afghan border area," Revista Brasileira de Farmacognosia, Vol. 28, No. 503, 2018, pp. 11.

[19] Hajj EM, Holst L., "Herbal medicine use during pregnancy: A review of the literature with a special focus on Sub-Saharan Africa," Front Pharmacol, Vol. 11, No. 866, 2020. www.ncbi.nlm.nih.gov/pmc/articles/PMC7296102/ (accessed 1 Jun 2021).

[20] Pengpid S, Peltzer K., "Use of traditional medicines and traditional practitioners by children in Indonesia: findings from a national population survey in 2014-2015," J Multidiscip Healthc, Vol. 12, No. 291, 2019, pp. 8.

[21] Sarmiento I, Zuluaga G, Andersson N., "Traditional medicine used in childbirth and for childhood diarrhoea in Nigeria's Cross River State: interviews with traditional practitioners and a statewide cross-sectional study," BMJ Open, Vol. 6, No 4, 2016. www.bmjopen.bmj.com/content /6/4/e010417.long (accessed 5 Jun 2021).

[22] Word Health Organization, "WHO Traditional Medicine Strategy 2014-2023". Hong Kong SAR, China: WHO: $25-8$.

[23] Fitrianti Y, Angkasawati TJ., "Gayo traditional medicine for postpartum mothers," Health System Research Bulletin, Vol. 18, No. 11, 2015, pp. 1-9. (In Indoensian)

[24] Shanthi RV, Jumari, Izzati M., "An ethnobotanical study of traditional medicine for the care of women in the Surakarta Hadiningrat Palace community," Bioscientific, Vol. 6, 2014, pp. 85-93. (In Indonesian)

[25] Yassir M, Asnah A., "Utilization of traditional medicinal plant species in Batu Hamparan Village, Southeast Aceh Regency," Biotic Journal, Vol. 6, 2018, pp. 17-34. (In Indonesian)

[26] BPS-Ternate. Ternate City in Figures 2020. Ternate City: BPS: 6-9.

[27] Sooi LK, Keng SL., "Herbal medicines: Malaysian women's knowledge and practice. Evid Based Complement Alternat Med 2013; www.ncbi.nlm.nih.gov/pmc/articles/P MC3777224/ (accessed 8 Jun 2021).

[28] Prastiwi RS., "Traditional medicine (jamu) in health care for postpartum and breastfeeding mothers in Tegal Regency," Cycle Journal, Vol. 7, 2018, pp. 3-7. (In Indonesian)

[29] Ahmed M, Hwang JH, Hasan MA, et al., "Herbal medicine use by pregnant women in Bangladesh: a cross-sectional study," BMJ Complement Altern Med, Vol. 18, No. 333, 2018. www.bmccomplementmedtherapies.biomedcentral.c om/articles/10.1186/s12906-018-2399-y (accessed 5 Jun 2021)

[30] Ahmed M, Im HB, Hwang JH, et al., "Disclosure of herbal medicine use to health care providers among pregnant women in Nepal: a cross-sectional study," BMC Complement Med Ther, Vol. 20, No. 339, 2020. www.bmccomplementmedtherapies.biomedcentral.com/art icles/10.1186/s12906-020-03142-9 (accessed 5 Jun 2021).

[31] Motti R, Bonanomi G, Emrick S, et al., "Traditional herbal remedies used in women's health care in Italy: A review," 
Human Ecology, Vol. 47, No. 9, 2019, pp. 41-72.

[32] Murugan P, Yared P., "Beliefs and practices of traditional medicine towards women's reproductive healthcare: Evidences from Wolaytta zone, Ethiopia," Ital Sociol Rev, Vol. 8, No. 1, 2018, pp. 57-85.

[33] Nordeng H, Al-Zayadi W, Diallo D, et al., “Traditional medicine practitioners' knowledge and views on treatment of pregnant women in three regions of Mali," J Ethnobiol

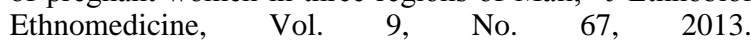
www.ethnobiomed.biomedcentral.com/articles/10.1186/17 46-4269-9-67 (accessed 5 Jun 2021).

[34] Shewamene Z, Dune T, Smith CA., "The use of traditional medicine in maternity care among African women in Africa and the diaspora: A systematic review," BMC Complement Altern Med, Vol. 17, No. 382, 2017. ww.bmccomplementmedtherapies.biomedcentral.com/artic les/10.1186/s12906-017-1886-x (accessed 8 Jun 2021).

[35] Eid AM, Jaradat N., "Public knowledge, attitude, and practice on herbal remedies used during pregnancy and lactation in West Bank Palestine," Front Pharmacol, Vol. 11, No. 46, 2020.www.frontiersin.org/articles/10.3389/fphar.2 020.00046/full (accessed 8 Jun 2021).

[36] Zakaria, Hadju V, As'ad S, et al., "Effect of extract Moringa oleifera on quantity and quality of breastmilk in lactating mothers, infants 0-6 month," Journal MKMI, Vol. 12, No. 16, 2016, pp. 1-9.

[37] Kristiyanti R, Khuzaiyah S, Chabibah N, et al., "Effectiveness of Moringa oleifera extract to increase breastmilk production in postpartum mother with food restriction," Advances in Social Science, Education and Humanities Research, Vol. 436, No. 58, 2019, pp. 4-9.

[38] Septadina IS, Murti K, Utari N., "The effect of giving Moringa leaf extract (Moringa oleifera) in the breastfeeding process," Sriwijaya Journal of Medicine, Vol. 1, No. 7, 2018, pp. 4-9. (In Indonesian)

[39] Indrayani D, Shahib MN, Husin F., "The Effect of katuk (Sauropus androgunus (L) Merr) leaf biscuit on increasing prolactine levels of breastfeeding mother," Jurnal Kesehatan Masyarakat, Vol. 16, 2020, pp. 1-7.

[40] Amornlerdpison D, Choommongkol V, Narkprasom K, et al., Bioactive compounds and antioxidant properties of banana inflorescence in a beverage for maternal breastfeeding," Appl Sci, Vol. 11, No. 343, 2021. www.doi.org/10.3390/app11010343 (accessed 8 Jun 2021).

[41] Widatiningsih S, Rofiah S, Ristiyanawati, "The use of brewed herbs mouthwash for overcoming morning sickness," Advances in Health Sciences Research, Vol. 13, No. 2, 2018, pp. 79-83.

[42] Zumaidar, Saudah, Rasnovi S, et al., "Indigenous knowledge of postnatal mother care using plants by Acehnese," IOP Conf. Series: Earth and Environmental Science, Vol. 364, 2019. www.iopscience.iop.org/article/1 $0.1088 / 1755-1315 / 364 / 1 / 012025 /$ pdf (accessed 8 Jun 2021).

[43] Agustina ZA, Fitrianti Y., "Utilization of jamu in puerperal mother in Sumatera and Java island (Literature review of health ethnographic researc 2012-2016)," The Indonesian Journal of Public Health, Vol. 15, 2020, pp. 93-102.

[44] Illamola SM, Amaeze OU, Krepkova LV, et al., "Use of herbal medicine by pregnant women: What physicians need to know," Front Pharmacol, Vol. 10, No. 1483, 2020. www.pubmed.ncbi.nlm.nih.gov/31998122/ (accessed 12 Jun 2021).

[45] Handayani L, Widowati L., "Further analysis of the empirical use of celery by traditional healers," Indonesian Pharmaceutical Journal, Vol. 10, 2020, pp. 31-41. (In Indonesian)

[46] Silalahi M., "The benefits and toxicity of areca nut (Areca catechu) in human health," Development of a Health Journal Generation," Vol. 11, 2020, pp. 26-31. (In Indonesian)

[47] Chue AL, Carrara VI, Paw MK, et al., "Is areca innocent? The effect of areca (betel) nut chewing in a population of pregnant women on the Thai-Myanmar border," Int Health, Vol. 4, No. 20, 2012, pp. 4-9.

[48] Garg A, Chaturvedi P, Gupta PC., "A review of the systemic adverse effects of areca nut or betel nut," Indian J Med Paediatr Oncol, Vol. 35, 2014, pp. 3-9.

[49] Lamadah SM, Hoda Abed El-Azim Mohamed HAE, El-Khedr SM., "Castor oil safety and effectiveness on labour induction and neonatal outcome," Journal of Biology, Agriculture and Healthcare, Vol. 4, 2014, pp. 1-10.

[50] Olagbende-Dada SO, Ukpo GE, Coker HAB, et al., "Oxytocic and anti-implantation activities of the leaf extracts of Graptophyllum pictum (Linn.) Griff. (Acanthaceae)," African Journal of Biotechnology, Vol. 8, No. 59, 2009, pp. 79-84.

[51] Ilyas HF.. "Traditional ingredients in Bugis culture," Walasuji Journal of History and Culture, Vol. 7, No. 1, 2020, pp. 39-52. (In Indonesian)

[52] Sarimole E, Martosupono M, Semangun H, et al., "Benefits of Jatropha (Jatropha curcas) as a traditional medicine," Proceedings of the Raja Ampat National Seminar: Study of benefits, nutrition and nutrition, 2014; pp. 9-12. (In Indonesian)

[53] Sossou Justin Adanmavokin, Sossou Gilles Armand, Igué Babatounde Charlemagne , Ouendo Edgard-Marius , "Application of the WHO Method of Workload Indicators of Staffing Needs to Evaluate Health Workers Availability and Capacity for Universal Health Coverage in Maternal and Child Health in Benin," Universal Journal of Public Health, Vol. 8, No. 5, pp. 163 - 178, 2020. DOI: 10.13189/ujph.2020.080502.

[54] Moussa Bachabi , Badirou Aguemon , Fernand Guédou , Rene Keke, Chaffa Oloukoi, Edgard Marius Ouendo, "Factors Associated with Successful Treatment among People Living with HIV: A Study in Cotonou Health Center 1 (Benin), 2018," Universal Journal of Public Health, Vol. 8, No. 3, pp. 104 - 112, 2020. DOI: 10.13189/ujph.2020.0803 04. 